\title{
THE CHANGE OF ROCK CONDITION OBSERVED BY H/V SPECTRAL AND ELLIPTICITY CURVE INVERSION ANALYSIS (CASE STUDY: PALU EARTHQUAKE SEPTEMBER 28, 2018)
}

\author{
Sandy Tri Gustono, Muhammad Akhadi*, Kekey Salsabil Azzahra, \\ Rika Adelina Ginting
}

Geophysics Department, College of Meteorology Climatology and Geophysics Perhubungan 1 Street, Number 5, Pondok Betung, Pondok Aren, Tangerang Selatan City, Banten, 15221, Indonesia

*Corresponding Author Email: muhammad.akhadi@stmkg.ac.id

Received: 27 July 2020

Revised: 14 October 2020

Accepted: 22 October 2020

Online: 1 December 2020

Published: 31 December 2020

SPEKTRA: Jurnal Fisika dan Aplikasinya p-ISSN: 2541-3384 e-ISSN: 2541-3392

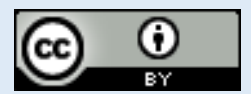

\begin{abstract}
Palu City is composed of sedimentary rocks so that it has a high level of vulnerability when an earthquake occurs. The earthquake that occurred on September 28, 2018, $25 \mathrm{~km}$ north of Donggala with a magnitude of 7.4 Mw, had caused a tsunami that struck Palu City, Sigi Regency, Donggala Regency, and Parigi Mouthong Regency, Central Sulawesi Province. This earthquake also caused liquefactions in the Petobo and Balaroa areas, Palu City, and Jono Oge in Sigi Regency. In this study, the authors used microtremor data at 8 points measured before and after the earthquake. Processing using the Horizontal to Vertical Spectra Ratio method shows that the predominant frequency and amplification factor changes due to changes in local rock conditions. The analysis also shows the value of soil vulnerability index $(\mathrm{Kg})$ mostly increased after the earthquake. Besides, the elliptic curve inversion method shows that before the earthquake event, the value of the $\mathrm{S}$ wave velocity (Vs30) in layer one was between 157.1$211.4 \mathrm{~m} / \mathrm{sec}$ with a layer thickness between 65.3-90.6 meters, while after the earthquake, the velocity becomes $156-214.6 \mathrm{~m} / \mathrm{sec}$ with a layer thickness ranging between 66-99.2 meters. This indicates that the area consists of soft and medium soils, which subsequently increased sediment thickness in most areas after the earthquake.
\end{abstract}

Keywords: Palu earthquake, microtremor, HVSR method, seismic vulnerability, Vs30 


\section{INTRODUCTION}

In the region of geology, the Palu area consists of alluvium deposits and coastal deposits (Qap) consisting of gravel, sand, mud, limestone in the shallow river, delta, and marine environments [1]. Most of the depressed areas of Palu City are clay, mud, and sand as alluvial deposits FIGURE 1. The presence of these sediments causes magnifying of the amplification factor at the ground surface when an earthquake occurs.

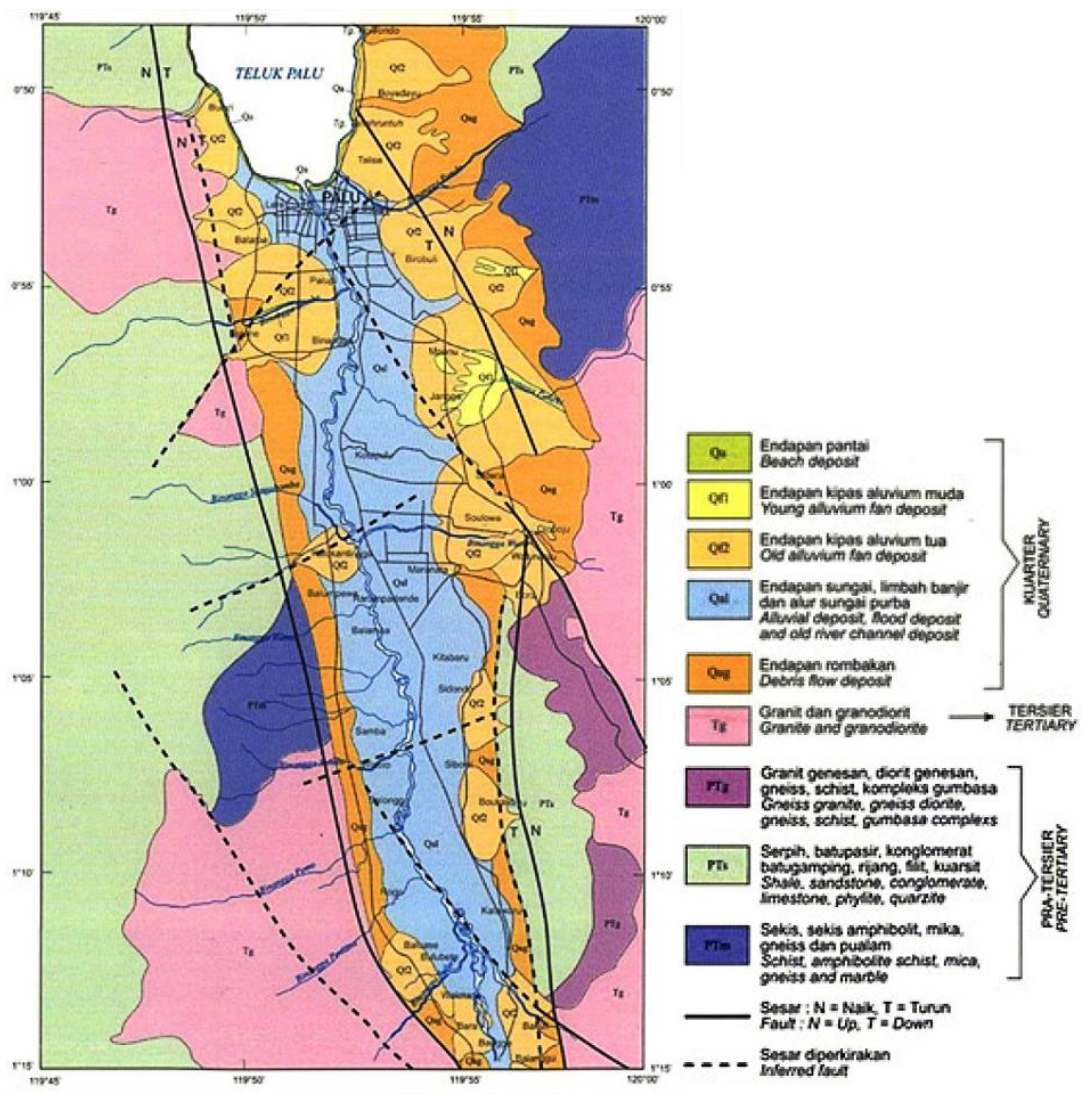

FIGURE 1. Geological map of Palu and its surroundings [2].

Tectonically, the Sulawesi region is an area with a complex structure. The subduction system of the Indo-Australian Plate makes this area earthquake-prone. The description of faults in the Sulawesi region has been found by several researchers with various methods. Most of the fault conditions are still active. Palu Koro Fault extends to $300 \mathrm{~km}$ from Palu City to Malili till Bone Bay. This type of fault is a sinistral strike-slip fault with a shift from the latest GPS measurements to 2016 with 20-40 mm/year [3]. This fault was formed due to microcontinent pressure from Banggai-Sula to the west due to the expansion of the Banda Sea to the northwest and southeast, thus pushing Buton and Banggai to move west. In addition, the Philippine Plate pushing westward is manifested by the presence of a large Sorong-Sula fault [1]. This fault is related to Matano-Sorong and Lawanoppo-Kendari Fault.

Earthquakes, tsunamis, and liquefaction are recorded as severe disaster events. The earthquake occurred on September 28, 2018, at 18:02:45 local time with an epicenter at $0.20^{\circ}$ South and $119.89^{\circ}$ East, $25 \mathrm{~km}$ north of Donggala at a depth of $11 \mathrm{~km}$ with tsunami potential. The 
earthquake that shook the Donggala Regency with a magnitude $7.4(\mathrm{Mw})$ caused an underwater landslide observed by aerial photography. This landslide caused the tsunami to Palu City, Sigi Regency, Donggala Regency, and Parigi Mouthong Regency, Central Sulawesi Province. Other impacts are surface rupture, soil cracks, liquefaction, and landslides.

Meanwhile, in Petobo and Balaroa, Palu City and Jono Oge area in Sigi Regency experienced liquefaction. Balaroa area is $1 \mathrm{~km}$ west of Palu-Koro Fault. The area affected by the liquefaction was $34.5 \mathrm{Ha}$ and a circumference of $2.5 \mathrm{~km}$, mostly houses, and roads. This incident is a phenomenon of loss of soil strength due to earthquake vibration. This occurs because the granular material changes in the sediment from solid to liquid as a consequence of increasing pore water pressure and decreasing effective stress [4]. Released from the BNPB report on October 20, 2018, there were 2,113 fatalities in the cities of Palu, Donggala, Sigi, Parigi Mountong, and Pasangkayu, West Sulawesi, 4,612 injured, 1,309 missing, and 68,451 houses damaged. The distribution of surface geological damage due to the earthquake is shown in FIGURE 2.

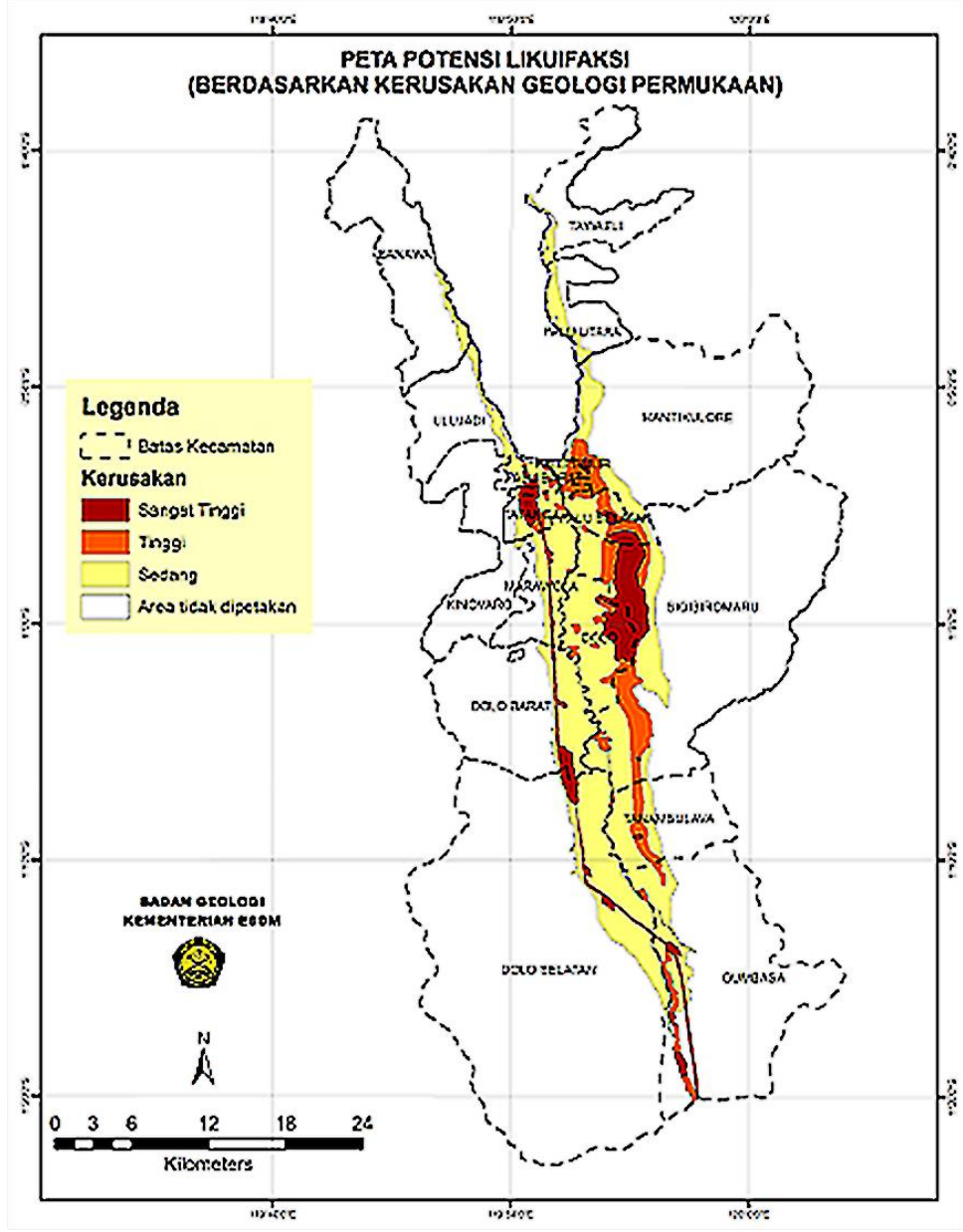

FIGURE 2. Map of potential liquefaction [5].

Several methods have been developed to analyze local geological conditions, one of which is the microtremor method. This method measures periodic vibrations due to natural and human activities. Several studies using microtremor are intended for vulnerability analysis of an area 
and shallow subsurface studies. At the same location, the characteristics of the microtremor signal will be identical when measured at different times [6].

This case will be different when an area experiences significant subsurface structural changes. This change can occur due to earthquakes that have a larger enough impact on an area. This is the reason for the author to conduct research on microtremor analysis in earthquake-affected areas. The analysis was performed on time-dependent microtremor measurement data (before and after an earthquake). This research is expected to provide an explanation related to the influence of local geological conditions on recorded microtremor signals.

\section{METHOD}

In this study, we used secondary microtremor data at eight points measured before and after the Palu earthquake on September 28, 2018. This data is the result of measurements from the team of Meteorology Climatology and Geophysics Agency (BMKG) and College of Meteorology Climatology and Geophysics (STMKG) in Palu City. The data used TABLE 3 close to the surface rupture and the Balaroa liquefaction area (FIGURE 3).

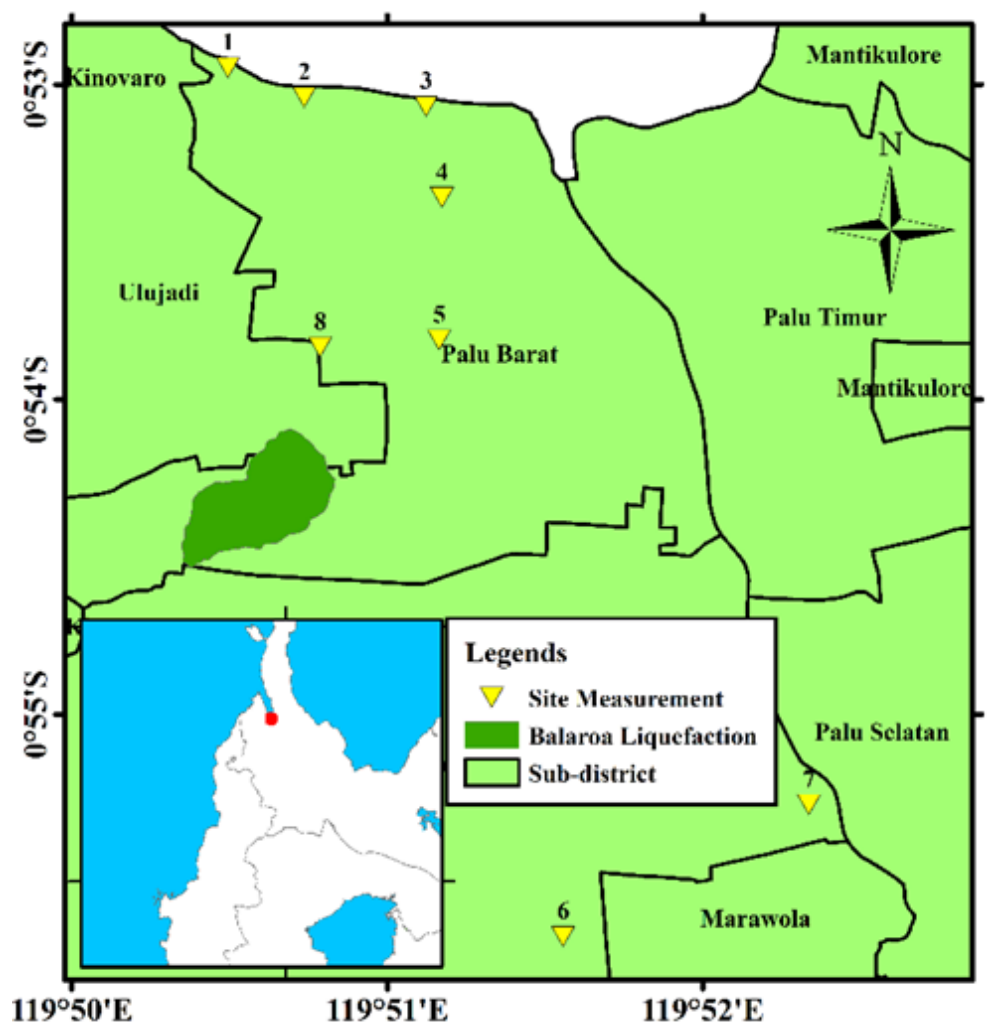

FIGURE 3. The locations of microtremor measurement (Map source: [7]). 
TABLE 1. Microtremor measurement point coordinates (MP ...: pre-earthquake data; PG ...: post-earthquake data)

\begin{tabular}{llll}
\hline Point & Latitude & Longitude & Name \\
\hline 1 & -0.88245 & 119.84159 & MP2141-01 \\
& -0.88241 & 119.84155 & PG-045 \\
& -0.88401 & 119.84562 & MP2142-21 \\
3 & -0.88401 & 119.84562 & PG-046 \\
& -0.8845 & 119.85206 & MP2142-17 \\
4 & -0.8845 & 119.85206 & PG-047 \\
& -0.88931 & 119.8529 & MP2142-15 \\
5 & -0.88928 & 119.85293 & PG-029 \\
& -0.89685 & 119.85275 & MP2142-14 \\
6 & -0.89665 & 119.85291 & PG-025 \\
& -0.92841 & 119.8593 & MP2144-12 \\
7 & -0.92835 & 119.85937 & PG-039 \\
& -0.92144 & 119.87229 & MP2144-01 \\
8 & -0.92145 & 119.87197 & PG-062 \\
& -0.89724 & 119.84646 & MP2142-19 \\
\hline
\end{tabular}

This study uses the Horizontal to Vertical Spectral Ratio (HVSR) method and elliptic curve inversion to determine soil conditions before and after the earthquake. The HVSR method is also called the Nakamura method, which was introduced by Nakamura in 1989. This method is used to determine the local site effect in an area by comparing the microtremor spectrum of the horizontal component to its vertical. The following are the basic concepts of the HVSR Method [8]:

1. The ratio of the maximum value of horizontal $\left(A_{H}\right)$ to vertical $\left(A_{V}\right)$ earthquake vibrations in bedrock is close to the value of one. Then, the transfer function $\left(S_{T}\right)$ in the surface layer is defined as EQUATION 2 where $S_{H S}$ is the horizontal tremor spectrum on the surface and $S_{H B}$ is the horizontal tremor spectrum in the bedrock $S_{T}=S_{H S} / S_{H B}$

2. The magnitude of the Rayleigh wave effect $\left(E_{S}\right)$ is calculated based on the ratio of vertical vibrations on the surface $\left(E_{V S}\right)$ to the bedrock $\left(E_{V B}\right)$. At the microtremor, it can be assumed that the Rayleigh wave effect is equal for the vertical and horizontal components, so $S_{T} / E_{S}$ can be considered to provide a more reliable $S_{\text {TT }}$ transfer function after eliminating the Rayleigh wave effect.

$S_{T T}=S_{T} / E_{S}=R_{S} / R_{B}$

where $R_{S}=S_{H S} / S_{V S}$ and $R_{B}=S_{H B} / S_{V B}$. Because $R_{B}$ value is 1 , so $S_{T T}$ value is equal to $R_{S}$.

3. This $S_{T T}$ or $R_{S}$ value describes the vibration effect without the influence of Rayleigh waves which is only caused by local geological conditions

4. The amplification magnification at the horizontal maximum value by the surface layers can be estimated by calculating the ratio of the horizontal to vertical maximum value on the surface.

HVSR analysis calculates the spectrum ratio of the horizontal component to the vertical component of a microtremor signal. The horizontal and vertical spectra were obtained from the fourier transformation of the microtremor signal in the EW, North-South (NS), and U-D (East-West) components. from time domain to frequency domain. 
Data processing uses the HVSR method with Geopsy software. This software has the ability to process ambient noise data so that it can help in site characterization [9]. Whereas the HVSR method was developed for estimating frequency values and amplification of local geological conditions using the ratio of horizontal to the vertical spectrum from noise data recording [8]. The results obtained in the form of a dominant frequency value associated with the depth of the field of seismic wave reflection, which is the boundary between loose sediment and bedrock. The smaller value of the frequency, the thicker sedimentary conditions [10]. While the amplification value is related to the magnification of seismic waves due to significant differences in the level of density between the layers. According to [11], amplification parameters can damage buildings if the value is greater than 3 and associated with low frequencies. Only horizontal component data are affected by soil conditions, while the source spectrum characteristics are in the vertical component [8].

Spectrum ratios will give the same results even though measurements are made at different times [6]. HVSR actually depends on the geological conditions in the area where the data is collected. Changes in rock conditions will give different HVSR spectrum results. In microtremors, time-dependent HVSR is useful to distinguish between the presence of the original dominant frequency associated with the resonance of subsurface structures and the emergence of fake amplification peaks due to temporary local conditions. The parameter measured values of ambient noise can be used to determine the type of soil using TABLE 2 and 3 .

TABLE 2. Classification of soil types based on NEHRP

\begin{tabular}{llll}
\hline Site Class & $\mathrm{T} 0(\mathrm{~s})$ & $\mathrm{Vs} 30(\mathrm{~m} / \mathrm{s})$ & NEHRP Class \\
\hline SC I: (Rock / compact soil) & $\mathrm{T} 0<0.2$ & $\mathrm{Vs} 30>600$ & $\mathrm{~A}+\mathrm{B}$ \\
SC II: (Hard soil) & $0.2 \leq \mathrm{T} 0<0.4$ & $300<\mathrm{Vs} 30 \leq 600$ & $\mathrm{C}$ \\
SC III: (Medium land) & $0.4 \leq \mathrm{T} 0<0.6$ & $200<\mathrm{Vs} 30 \leq 300$ & $\mathrm{D}$ \\
SC IV: (Soft ground) & $\mathrm{T} 0 \geq 0.6$ & $\mathrm{Vs} 30 \leq 200$ & $\mathrm{E}$ \\
\hline
\end{tabular}

TABLE 3. Classification of soil types based on Vs30 (SNI 1726: 2012)

\begin{tabular}{ll}
\hline Land Classification & $\mathrm{V}_{\mathrm{S} 30}(\mathrm{~m} / \mathrm{dt})$ \\
\hline SE (Soft Land) & $<175$ \\
SD (Medium Land) & $175<\mathrm{V}_{\mathrm{S}} \leq 350$ \\
SC (Hard Soil, Soft Rock) & $350<\mathrm{V}_{\mathrm{S}} \leq 750$ \\
SB (Rock) & $<\mathrm{V}_{\mathrm{S}} \leq 1500$ \\
SA (Rock Hard) & $>1500$ \\
\hline
\end{tabular}

In addition, the measured parameter values are also used to determine the seismic vulnerability index, which describes the level of surface soil susceptibility to deformation during an earthquake so that it can be useful for the prediction of zones prone to liquefaction and fractures [12]. Seismic vulnerability index values are influenced by amplification factors and resonant frequencies [11]. 


$$
K g=\frac{A^{2}}{f_{0}}
$$

Ground shaking is influenced by surface geological conditions represented by the average shear velocity value at a depth of $30 \mathrm{~m}$ (Vs30) from the total thickness of the sediment above the bedrock [13]. The presence of this surface sediment can amplify the ground shaking during an earthquake. Microtremor analysis can be useful for obtaining the Vs30 value. The method used is the inverse of the Rayleigh wave ellipticity curve, which is a surface wave resulting from $\mathrm{P}$ and SV reflected wave interference. The ratio between horizontal and vertical particle motion is the ellipticity of the Rayleigh wave. The elliptical inversion of Rayleigh waves can be modeling the subsurface structure to obtain the elastic parameters of the dispersion curve. In this study, we assume the number of rock layers in the study area consists of 3 layers. In each layer, we define the input parameter constraints in the form of a range for $\mathrm{Vp}$, Vs, Poisson Ratio, and Density values. We use the same constraints at each measurement point for the inversion process. With this treatment, we can observe changes in the value of Vs and the layer depth in the measurement point before and after the earthquake occurred, although it is possible that the results obtained are slightly different from the actual local geological conditions.

\section{RESULT AND DISCUSSION}

\section{Horizontal to Vertical Spectral Ratio (HVSR) Analyses}

Geopsy treatment produces the values written in Table 4. The type of soil is based on the value of Tdom at each point. From these soil types, it can be seen that the conditions in the Palu region are all covered by sedimentary rocks. Figure 4 shows an example of the HVSR spectrum from MP2144-12 data (before the earthquake) and PG-039 (after the earthquake) at the same location.

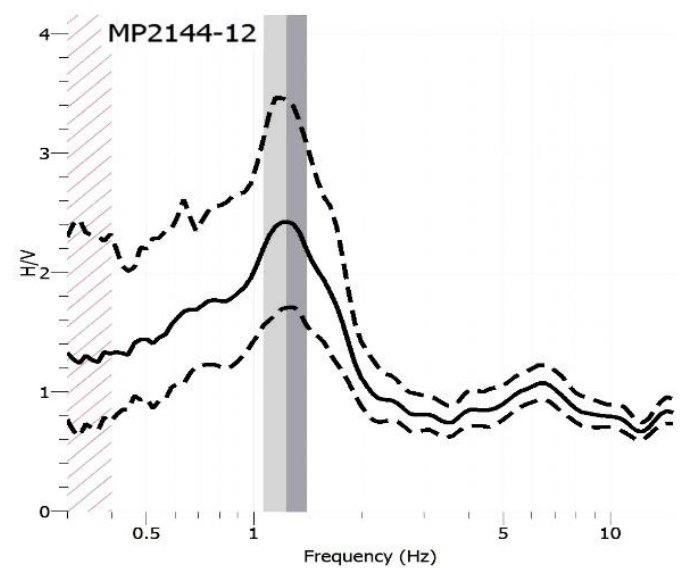

(a)

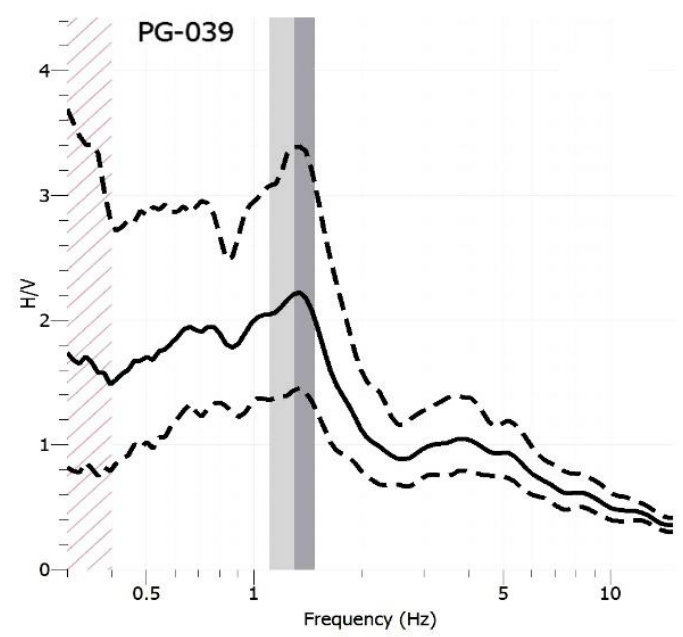

(b)

FIGURE 4. HVSR processing results: (a) MP2144-12 (pre-earthquake data); (b) PG-039 (post-earthquake data) 
The results of data processing using the HVSR method are shown in Table 4. The value of the dominant period before the earthquake ranged from 0.802858 seconds to 2.229321 seconds. While the value of the dominant period after the earthquake ranged from 0.805977 seconds to 4.26603 seconds. This value indicates the rock in the study area consists of soft soil (SE). The value of the dominant period of land from the measurement point mostly increases, which indicates that the rock has changed into softer compactness due to the earthquake wave factor that changes the rock structure.

TABLE 4. The value of dominant frequency, amplification factor, and dominant period and site classification

\begin{tabular}{|c|c|c|c|c|c|}
\hline Points & Name & f0 & A0 & Tdom & $\begin{array}{l}\text { Site Class } \\
\text { (NEHRP) }\end{array}$ \\
\hline \multirow[t]{2}{*}{1} & MP2141-01 & 0.660536 & 4.04759 & 1.513922 & $\mathrm{SE}$ \\
\hline & PG-045 & 0.381181 & 4.07528 & 2.623426 & SE \\
\hline \multirow[t]{2}{*}{2} & MP2142-21 & 0.549785 & 3.5121 & 1.818893 & SE \\
\hline & PG-046 & 0.428017 & 5.3278 & 2.336356 & SE \\
\hline \multirow[t]{2}{*}{3} & MP2142-17 & 0.475705 & 3.84861 & 2.102143 & $\mathrm{SE}$ \\
\hline & PG-047 & 0.423208 & 6.67103 & 2.362904 & SE \\
\hline \multirow[t]{2}{*}{4} & MP2142-15 & 0.494322 & 4.23462 & 2.022973 & SE \\
\hline & PG-029 & 0.55489 & 4.54432 & 1.802159 & SE \\
\hline \multirow[t]{2}{*}{5} & MP2142-14 & 0.575597 & 3.71524 & 1.737327 & SE \\
\hline & PG-025 & 0.23441 & 2.65422 & 4.26603 & $\mathrm{SE}$ \\
\hline \multirow[t]{2}{*}{6} & MP2144-12 & 1.24555 & 2.46336 & 0.802858 & SE \\
\hline & PG-039 & 1.24073 & 2.32317 & 0.805977 & SE \\
\hline \multirow[t]{2}{*}{7} & MP2144-01 & 0.877911 & 2.91675 & 1.139068 & SE \\
\hline & PG-062 & 0.278674 & 3.055 & 3.588422 & $\mathrm{SE}$ \\
\hline \multirow[t]{2}{*}{8} & MP2142-19 & 0.448567 & 3.35821 & 2.229321 & $\mathrm{SE}$ \\
\hline & PG-026 & 0.666097 & 3.53735 & 1.501283 & $\mathrm{SE}$ \\
\hline
\end{tabular}

\section{Seismic Vulnerability Index}

Seismic vulnerability index values describe the condition of an area that has the potential to experience shocks due to earthquakes. The higher the value, the more vulnerable it is due to the earthquake. The Palu area is a sedimentary area, so it has a high vulnerability index. After the earthquake occurred on September 28, 2018, there were liquefaction in Petobo and Balaroa, Palu City, and Jono Oge area in Sigi Regency. The result of the seismic vulnerability index calculation from the HVSR analysis is shown in TABLE 5.

The seismic vulnerability index after the earthquake is dominant because of the liquefaction process that causes the soil structure to change to be more vulnerable to earthquakes. Seismic vulnerability index before earthquake between 4.87185781 to 36.2759629 . While the seismic vulnerability index after the earthquake between 4.34995434 to 105.155482 . The seismic vulnerability index after the earthquake increased to three times from the initial seismic vulnerability index. This value indicates a condition in which changes in the upper rock layer are increasingly vulnerable to shocks when an earthquake occurs. 
TABLE 5. The value of Seismic Vulnerability Index $(\mathrm{Kg})$ based on measurement time

\begin{tabular}{llll}
\hline Point & Name & Kg & Information \\
\hline 1 & MP2141-01 & 24.8025616 & Increase \\
& PG-045 & 43.5696089 & \\
2 & MP2142-21 & 22.4357638 & Increase \\
& PG-046 & 66.3185173 & \\
3 & MP2142-17 & 31.1365214 & Increase \\
4 & PG-047 & 105.155482 & \\
& MP2142-15 & 36.2759629 & Increase \\
5 & PG-029 & 37.2161046 & \\
& MP2142-14 & 23.9803339 & Increase \\
6 & PG-025 & 30.0536829 & \\
7 & MP2144-12 & 4.87185781 & Decrease \\
7 & PG-039 & 4.34995434 & \\
8 & MP2144-01 & 9.69053875 & Increase \\
& PG-062 & 33.4908352 & \\
\hline
\end{tabular}

\section{Shear Wave Velocity (Vs30)}

An inversion of microtremor signals has been carried out with ellipticity curves with certain parameter constraints in the form of a range for $\mathrm{Vp}, \mathrm{Vs}$, Poisson Ratio, and Density values. The value of shear wave velocity from Horizontal to Vertical Spectral Ratio (HVSR) inversion can be seen in Table 6. The soil layers below each measurement point are assumed to be 3 layers and produce different Vs values at each measurement point before and after the earthquake. Misfit produced is less than 1 so the results of this inversion are considered appropriate.

TABLE 6. Vs30 values $(\mathrm{m} / \mathrm{s})$ and the depth of the upper layer $(\mathrm{m})$.

\begin{tabular}{|c|c|c|c|c|c|c|}
\hline \multirow{2}{*}{ Point } & \multirow{2}{*}{ Name } & \multicolumn{2}{|c|}{ Upper Layer } & \multirow{2}{*}{ Misfit } & \multirow{2}{*}{$\begin{array}{l}\text { Site Class } \\
\text { (SNI 1726:2012) }\end{array}$} & \multirow{2}{*}{$\begin{array}{l}\text { Site Class } \\
\text { (NEHRP) }\end{array}$} \\
\hline & & Vs30 & Depth & & & \\
\hline \multirow[t]{2}{*}{1} & MP2141-01 & 164.1 & 69.3 & 0.254069 & SE & SE \\
\hline & PG-045 & 214.6 & 82 & 0.274528 & SD & SD \\
\hline \multirow[t]{2}{*}{2} & MP2142-21 & 157.2 & 67.1 & 0.273346 & $\mathrm{SE}$ & $\mathrm{SE}$ \\
\hline & PG-046 & 158.3 & 74.9 & 0.26198 & SE & SE \\
\hline \multirow[t]{2}{*}{3} & MP2142-17 & 174.3 & 73.5 & 0.273162 & SE & SE \\
\hline & PG-047 & 178.4 & 78.9 & 0.262395 & SD & SE \\
\hline \multirow[t]{2}{*}{4} & MP2142-15 & 211.4 & 90.6 & 0.264676 & SD & SD \\
\hline & PG-029 & 160.7 & 70.7 & 0.264836 & SE & $\mathrm{SE}$ \\
\hline \multirow[t]{2}{*}{5} & MP2142-14 & 178.8 & 77.3 & 0.258342 & SD & SE \\
\hline & PG-025 & 162.2 & 72.1 & 0.256763 & SE & SE \\
\hline \multirow[t]{2}{*}{6} & MP2144-12 & 157.1 & 65.3 & 0.260362 & SE & $\mathrm{SE}$ \\
\hline & PG-039 & 156 & 66 & 0.251215 & SE & SE \\
\hline \multirow[t]{2}{*}{7} & MP2144-01 & 190.2 & 78.82 & 0.27237 & SD & SE \\
\hline & PG-062 & 214.4 & 99.2 & 0.267692 & SD & SD \\
\hline \multirow[t]{2}{*}{8} & MP2142-19 & 160.5 & 74.1 & 0.258656 & SE & SE \\
\hline & PG-026 & 164.5 & 75 & 0.253047 & SE & SE \\
\hline
\end{tabular}


The value of shear wave velocity to a depth of 30 meters (Vs30) in Palu depression is lower than the surrounding area $(\mathrm{Vs} 30 \leq 180 \mathrm{~m} / \mathrm{sec})[14]$. Vs30 values before the earthquake ranged from $157.1 \mathrm{~m} / \mathrm{s}$ to $211.4 \mathrm{~m} / \mathrm{s}$. While the value of Vs30 after the earthquake ranged from 156 $\mathrm{m} / \mathrm{s}$ to $214.6 \mathrm{~m} / \mathrm{s}$. This Vs30 value indicates that rock in this region consists of soft and medium soils.

The depth value of the first layer before the earthquake ranged from 65.3 meters to 90.6 meters, and after the earthquake, it ranged from 66 meters to 99.2 meters. This value is in accordance with the research on the depth of bedrock in Palu, which reaches 390 meters [13]. This value indicates a change in the thickness of the sediments in the area, most of which have increased in thickness.

FIGURE 5 below shows an example of the HVSR inversion results on MP2144-12 data (before the earthquake) and PG-039 (after the earthquake). It can be seen that the misfit value obtained is 0.3 (less than 1). It means that the inversion is correct, and the results are close to the actual conditions.

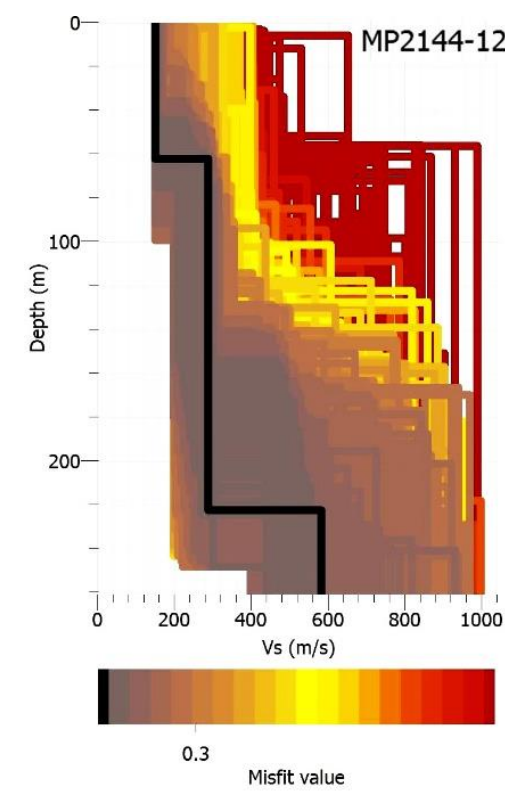

(a)

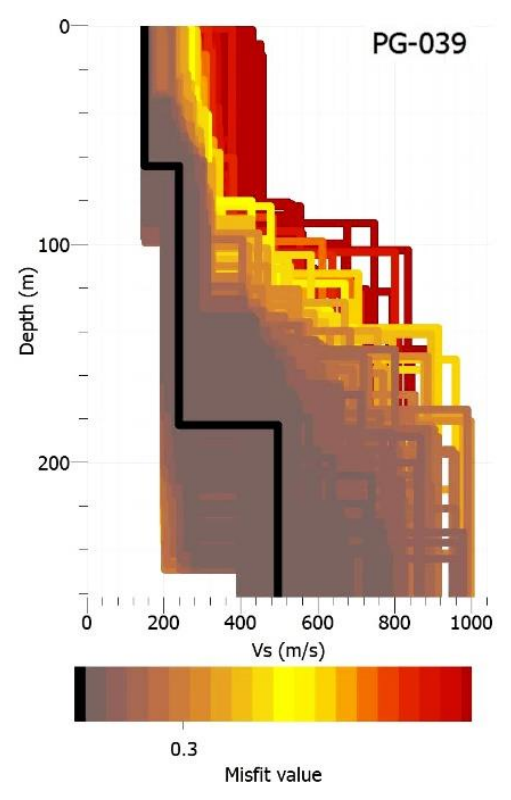

(b)

FIGURE 5. The results of ellipticity curve inversion: (a) MP2144-12 (pre-earthquake data); (b) PG-039 (post-earthquake data)

\section{CONCLUSION}

Based on the result of this research, the value of the dominant period before the earthquake ranged from $0.802858 \mathrm{~s}$ to $2.229321 \mathrm{~s}$. While the value of the dominant period after the earthquake ranged from $0.805977 \mathrm{~s}$ to $4.26603 \mathrm{~s}$. This value indicates the rock in the study area consists of soft soil (SE).

Dominant period parameters, seismic vulnerability index, and shear wave velocity (Vs30) from the analysis indicate changes in local rock conditions in which physical parameters of rocks after the earthquake mostly become softer than before the earthquake. In addition, 
changes in the thickness of the sedimentary layer, which mostly increases, indicate a physical change in the form of rock density in the first layer, which is getting lower. This can cause even more dangerous amplification if a significant earthquake occurs in the future.

The assumption of 3 layers with identical parameter constraints in each measurement point might give a little bit different result with local geological conditions. Therefore, further research must pay attention to information on very local geological conditions to obtain more representative of the actual conditions. This research itself is still limited to the method that is used, so there is still a need for measurement with a more accurate method such as SPT (Standard Penetration Test) or CPT (Cone Penetration Test) with lab analysis for further research so that better results are obtained.

\section{ACKNOWLEDGMENTS}

The authors would like to express thanks to the team of Meteorology Climatology and Geophysics Agency (BMKG) with the College of Meteorology Climatology and Geophysics (STMKG), which have provided microtremor data of pre and post of Palu earthquake.

\section{REFERENCES}

[1] N. R. Hanifa and Supartoyo, "Tektonik Sulawesi," in Kajian Gempa Palu Provinsi Sulawesi Tengah 28 September 2018 (M7,4), Tim Pusat Studi Gempa Nasional, Ed. Bandung, Indonesia: Pusat Penelitian dan Pengembangan Perumahan dan Permukiman, Badan Penelitian dan Pengembangan, Kementerian Pekerjaan Umum dan Perumahan Rakyat, pp. 9-15, 2018.

[2] A. Soehaimi et al., "Peta Zonasi Kerentanan Bencana Gempabumi Daerah Palu dan Sekitarnya," Bandung, Indonesia: Pusat Penelitian dan Pengembangan, Badan Geologi, 2000.

[3] I. Meilano et al., "Tektonik Geodesi Indonesia," in Peta Sumber dan Bahaya Gempa Indonesia Tahun 2017, Tim Pusat Studi Gempa Nasional, Ed. Bandung, Indonesia: Pusat Penelitian dan Pengembangan Perumahan dan Permukiman, Badan Penelitian dan Pengembangan, Kementerian Pekerjaan Umum dan Perumahan Rakyat, pp. 119-191, 2017.

[4] W. F. Marcuson, "Definition of Terms Related to Liquefaction," in Journal of The Geotechnical Engineering Division, vol. 104, no. 9, pp. 1197-1200, 1978.

[5] W. Hermawan et al., "Sebaran Kerusakan Geologi Permukaan," in Di Balik Pesona Palu, Bencana Melanda, Geologi Menata, A. W. Kusumah M. et al., Ed. Bandung, Indonesia: Badan Geologi, Kementerian Energi dan Sumber Daya Mineral, pp. 101-111, 2018.

[6] J. Almendros et al., "Microtremor Analyses at Teide Volcano (Canary Island, Spain): Assessment of Natural Frequencies of Vibration Using Time-dependent Horizontal-tovertical Spectral Ratios," in Pure and Applied Geophysics, vol. 161, pp. 1579-1596, 2004.

[7] Badan Informasi Geospasial. (2018). Pusat Pengelolaan dan Penyebarluasan Informasi Geospasial Badan Informasi Geospasial (BIG). Peta Terdampak Gempabumi dan 
Tsunami [Online]. Available: https://tanahair.indonesia.go.id/portalweb/bencana/metadata_sulteng.html

[8] Y. Nakamura, "A Method for Dynamic Characteristics Estimation of Subsurface using Microtremor on the Ground Surface," in Quarterly Report of RTRI, Vol. 30, no. 1, pp. 25-33, 1989.

[9] C. Acerra, H. B. Havenith, and S. Zacharopoulos, "Guidelines for the Implementation of the H/V Spectral Ratio Technique on Ambient Vibration: Measurement, Processing and Interpretation," SESAME European research project, European CommissionResearch General Directorate, 2004.

[10] N. Haerudin et al., "Earthquake Disaster Mitigation Mapping by Modeling of Land Layer and Site Effect Zone in The Kota Baru of South Lampung," in Jurnal Pendidikan Al Biruni, Vol. 1, no. 8, 2019.

[11] Y. Nakamura et al., "Local Site Effect of Kobe Based On Microtremor Measurement," in Proceedings of the Sixth International Conference on Seismic Zonation (6 ISCZ) EERI, California, 2000.

[12] H. C. Huang and Y. S. Tseng, "Characteristics of soil liquefaction using H/V of microtremors in Yuan-Lin Area, Taiwan," in TAO, Vol. 13, no. 3, pp. 325-338, 2002.

[13] A. Omang et al., "Menghitung Guncangan Gempabumi" in Di Balik Pesona Palu, Bencana Melanda, Geologi Menata, A. W. Kusumah M. et al, Ed. Bandung, Indonesia: Badan Geologi, Kementerian Energi dan Sumber Daya Mineral, pp 57-70, 2018.

[14] A. Cipta and A. Solikhin, "Pendugaan Kecepatan Gelombang Permukaan (VS30) di Pulau Sulawesi Berdasarkan Klasifikasi Geomorfologi dan Aplikasinya," in Jurnal Gunung api dan Mitigasi Bencana Geologi, vol. 3, no. 2, 2011. 